\title{
IDENTIFIKASI KARAKTER IDEAL KONSELI MENURUT TEKS KEPRIBADIAN FOUNDING FATHERS INDONESIA: KAJIAN DALAM PERSPEKTIF FROMM
}

\author{
Restu Dwi Ariyanto, Andi Mappiare-AT, Moh. Irtadji \\ email: restu.d.ariyanto@gmail.com
}

\begin{abstract}
Abstrak
Penelitian ini dilaksanakan untuk pemaknaan teks kepribadian Founding Fathers Indonesia (FFI) sebagai karakter ideal konseli. Tujuan penelitian ini adalah 1) mendeskripsikan hidup produktif menurut FFI yang dapat diserap menjadi karakter ideal konseli; 2) mendeskripsikan perilaku kerjasama menurut FFI yang dapat diserap menjadi karakter ideal konseli; 3) mendeskripsikan sikap menghargai menurut FFI; 4) mendeskripsikan nilai kepribadian lain menurut FFI yang dapat diserap menjadi karakter ideal konseli. Penelitian ini menggunakan pendekatan kualitatif dengan tipe hermeneutik Gadamerian. Hasil penelitian menunjukkan bahwa karakter ideal konseli menurut FFI terdiri dari 1) hidup produktif: pola hidup sederhana, kontrol diri, dinamis, tidak bergantung pada bangsa lain, cinta produk dalam negeri, normatif, inovatif, rela berkorban, dan kebebasan; 2) perilaku kerjasama: rasa setiakawan, kesesuaian pedoman, dan nasionalisme-internasionalisme; 3) menghargai: musyawarah dan mufakat, bijaksana, dan toleransi; 4) nilai kepribadian lain meliputi 4.1) religius: keyakinan, pancasila sebagai pedoman dan rasional; 4.2) nasionalis: humanis, persatuan, dan cinta-damai. Sedangkan implikasi dalam bimbingan dan konseling sesuai dengan Standar Kompentensi Kemandirian Peserta Didik (SKKPD). Saran yang diajukan dalam penelitian ini adalah konselor dapat menggunakan hasil penelitian ini sebagai bahan identifikasi karakter ideal konseli. Peneliti yang berminat mengadaptasi hasil temuan ini hendaknya menggunakan subjek yang lebih luas, menggunakan varian metode hermeneutik, menggunakan varian teori konseling khususnya rumpun humanisme atau teori konseling lain dari barat maupun Indonesia, dan menggunakan buku teks bermuatan karakter yang lebih variatif.
\end{abstract}

Kata Kunci: Karakter, Teks Kepribadian, Founding Fathers Indonesia

\section{Abstract}

This research been conducted for meaning the text of Indonesian Founding Fathers (IFF) as counselee's ideal character. The purpose of the research are 1) describing productivity life according to IFF can be considered to be counselee's ideal character; 2) describing cooperative behavior according to IFF can be considered to be counselee's ideal character; 3) describing respecting attitude according to IFF can be considered to be counselee's ideal character; 4) describing other value of personality according to IFF can be considered to be counselee's ideal character. This research using qualitative approach by Gadamerian hermeneutic type. Result of the reseach show that counselee's ideal character according to IFF including 1) productivity life, simplicity life form, self control, dinamic, not depending on anothers nation, love domestic product, normative, inovative, sucrificion, and freedom; 2) cooperative attitude, solidarity, according to the rule, nationalism-internationalism 3) Respecting, disccussing and making decision, and tolerance; 4) other Personality value including: 4.1. Religion, belief, pancasila as rule and rational; 4.2. nationalism, humanism, unity, and love peace. Next, the implication for the guidance and counseling according to the standard compentency otonomy of student. The recomendation which is recommending on this reserch, counselor should be using the result of this research as course of counselee's ideal character identification. The next researcher, whom interest adopting this result should using the large subject, using variaty hermeneituc methode, using variaty counseling theory, specialy in humanism area or other counseling theory form west or Indonesia, and using text book, which content variatif character.

Keywords: Character, personality text, Indonesian Founding Fathers

\section{PENDAHULUAN}

Karakter adalah gambaran diri manusia secara bulat dan utuh yang membuat unik dengan manusia lain. Dapat diartikan bahwa karakter merupakan wujud dari keseluruhan pikiran, perasaan dan perilaku yang dimiliki oleh manusia. Keseimbangan antara ketiga komponen tersebut akan menciptakan suatu bentuk karakter yang ideal. Karakter tersebut diharapkan dapat 
muncul pada konseli di lingkungan sekolah. Konseli adalah individu yang mendapatkan bantuan layanan profesional konselor dengan tujuan untuk memfasilitasi pencapaian tahap perkembangan secara maksimal. Tahap ini konseli memasuki periode post-modern dimana individu butuh kebebasan berekspresi-diri dan rasa aman dalam menjalani kehidupan sebagai individu (human being).

Berdasarkan deskripsi di atas, dilakukan studi pendahuluan di Madrasah Aliyah Negeri Purwoasri sejak awal bulan Januari 2014 sampai Mei 2014. Madrasah merupakan lembaga pendidikan yang lebih selektif dalam memberikan ajaran khususnya nilai-nilai religius untuk dapat diterapkan dalam dinamika kehidupan baik di Madrasah maupun lingkungan sosial konseli. Ditemukan beragam fenomena lapangan yang menggambarkan keadaan karakter konseli. Fenomena awal yang ditemukan terkait karakter pribadi konseli yaitu perilaku hidup tidak sederhana atau cenderung bergaya hidup mewah. Perilaku hidup mewah artinya bahwa konseli menjukkan perilaku hidup tidak sederhana yang terlihat pada beberapa konseli di Madrasah. Berdasarkan wawancara dengan salah satu konseli ditemukan bahwa.

Kalau menurut saya, saya belum mampu menerapkan hidup sederhana pak. Misalnya saya masih minta dibeliin hape bagus dan laptop. Karena hal tersebut adalah barang-barang yang wajib saya miliki di kelas. Saya ndak mau dikira anak orang gak punya, ya meskipun saya anak seorang petani. Saya pernah minggat dari rumah gara-gara minta motor baru. Padahal yang saya sadar motorku masih bagus, tapi saya pengen yang bagus lagi. (DW/KI/16/Mei/2014).

Peristiwa di atas dapat diartikan bahwa ada semacam pola perilaku yang mengarah pada gaya hidup mewah dalam diri konseli. Perilaku bergaya hidup mewah tersebut timbul akibat kebutuhan untuk dihargai dan diakui oleh konseli yang lain (significant others). Kebutuhan akan penghargaan dan pengakuan merupakan wujud dalam salah satu orientasi karakter penimbun (hoarding) (Feist \& Feist, 2008: 199-200; Friedman, 2013:148; Schultz \& Schultz, 2005: 184185). Terkait hal tersebut, didapatkan alasan salah satu konseli mengapa perilaku gaya hidup mewah muncul.

Saya begini karena saya melihat dalam TV, semua apa yang tak lihat di tayangan TV pake hape bagus pak, itu keren buat saya, saya pikir kalo saya punya hape dan motor bagus saya akan dianggap gaul dan gak kuper. Makanya saya ngotot banget minta bapak untuk beliin hape Samsung android dan motor biar bisa kelihatan eksis di sekolah (DW/KI/4/Mei/2014).
Argumen di atas menandakan bahwa ada semacam kebutuhan akan kepemilikan benda sebagai wujud eksistensi-diri konseli. Hal tersebut menandakan bahwa konseli menempatkan benda sebagai wujud properti simbol kedudukan sosial (Feist \& Feist, 2008: 199; Friedman, 2013: 148; Fromm, 1975: 88; 1976 :57; Schultz \& Schultz, 2005: 184). Pernyataan tersebut menandakan bahwa benda sebagai wujud properti akan menempatkan konseli merasa dihargai dan diakui dalam proses interaksi sosial di madrasah.

Merujuk pada fakta yang telah disampaikan pada kalimat sebelumnya, pola hidup berlebih-lebihan terlihat berseberangan dengan perilaku hidup sederhana yang pernah diwacanakan secara tertulis dalam teks karakter Founding Fathers Indonesia. Petikan teks karakter Founding Fathers menyatakan bahwa "ya, kalau kita mendapat kesenangan, itu rahmat dari Tuhan dan sepantasnya kita mengucapkan alhamdulillah. Tidak perlu kita bersikap berlebihlebihan dan terus pesta-pesta" (DT2/1989/193/PA/Kal1).

Penggalan fakta yang terjadi dilapangan dan teks Founding Fathers Indonesia tersebut senada dengan konsep hidup produktif yang diutarakan oleh Fromm. Hal tersebut dapat dimaknai bahwa kesederhanaan atau perilaku hidup produktif tidak perlu ditunjukkan dengan hal-hal yang berlebihan, yaitu membeli barang-barang mewah tidak tepat guna seperti dalam jabaran fakta di atas. Perilaku hidup produktif dapat diwujudkan dengan membeli motor dan HP tidak mahal, yang terpenting asas manfaat sebagai alat transportasi dan komunikasi. Oleh sebab itu kemampuan hidup produktif sangat diperlukan dalam upaya membuat pertimbangan-pertimbangan kepada konseli dalam menentukan suatu tindakan yang tepat.

Berdasarkan fakta tentang perilaku kedisiplinan, ditemukan fakta kedua di lapangan yaitu terkait perilaku kerjasama antar siswa. Pembiasaan perilaku kerjasama akan muncul ketika berada dalam situasi interaksi sosial, dimana konseli harus berhubungan dengan lingkungan sosial. Hal tersebut dapat terlihat dalam petikan argumen konseli berikut.

kerjasama tuh kayak gotong-royong nggeh pak..hehe. Alhamdulillah klo di MAN sini anak-anaknya kompak kok pak klo soal kerjasama, kami iklhas berbuat baik pada sesama pak. ya...misalnya saat ada temen kena musibah entah itu kecelakaan atau ada salah satu anggota keluarga ada yang meninggal, saya akan kerjasama dengan teman-teman yang lain untuk membantunya baik memberikan uang maupun mensupport dengan motivasi. Ya paling tidak bisa meringankan beban teman saya yang kena musibah pak..hehehe..Kemudian saat ada bencana Kelud kemarin, siswa juga akan kerjasama memberikan sumbangan uang, mereka juga ada 
yang sukarela membantu di posko bencana di daerah Puncu namun ya itu tadi pak, kita nunggu OSIS dan Guru bergerak duluan baru kita ikut...hehe (DW/KI/16/Mei/2014).

Paparan konseli tersebut dapat dimaknai bahwa perilaku kerjasama akan muncul sebagai wujud kepedulian antar sesama konseli. Wujud kepedulian antar sesama didasarkan oleh kebutuhan dasar manusia yaitu kebutuhan akan keterhubungan (relatednesss) antara manusia yang satu dengan yang lain (Feist \& Feist, 2008: 192; Friedman, 2013: 152; Fromm, 1955: 32; Funk, 2009: 76).

Fakta yang terlihat di atas menjukkan bahwa aspek cinta (loving) menjadi indikator utama dalam menampilkan sikap pedui terhadap sesama konseli. Fromm (dalam Feist \& Fiest, 2008: 200) menjelaskan bahwa perilaku kerjasama merupakan orientasi karakter produktif yang ditandai dengan rasa saling mencintai dalam membantu sesama. Fromm menegaskan perilaku mencintai sesama manusia dalam dinamika kehidupan sosial (brotherly love) ditandai dengan "love for all human being...experience of union with all men, of human solidarity, of human atonement" (Fromm, 1957: 37). Hal ini dapat tarik makna bahwa perasaan saling mencintai sesama manusia akan menciptakan kehidupan yang dipenuhi oleh solidaritas antar manusia.

Perilaku saling mencintai sesama manusia ini senada dengan harapan yang pernah diutarakan dalam teks Founding Fathers Indonesia "gotong royong sudah mendarah daging dalam jiwa kami bangsa Indonesia. Dalam masyarakat yang asli kami tidak mengenal kerja dengan upah. Manakala harus dilakukan pekerjaan yang berat, setiap orang turut membantu" (DT1/2001/35/PA3/Kal1).

Uraian teks di atas mengandung makna bahwa perilaku gotong royong merupakan salah satu bentuk perilaku kerjasama. Perilaku tersebut dahulu merupakan wacana yang sudah menjadi kebiasaan dan budaya bagi masyarakat Indonesia. Hal ini menandakan bahwa kerjasama merupakan salah satu kebutuhan dasar eksistensi manusia. Fromm (1955: 3336) mengatakan bahwa kebutuhan eksistensial manusia meliputi keterhubungan (relatedness), keunggulan (transcendence), keberakaran (rootedness), identitas (sense of identity) dan kerangka orientasi (frame of orientation). Kelima kebutuhan eksistensial tersebut akan mendorong manusia mencapai orientasi karakter ideal.

Beranjak pada fakta ketiga, ditemukan bahwa konseli masih belum menunjukkan perilaku menghargai (respect) ketika dihadapkan pada situasi interaksi sosial. Berdasarkan wawancara dengan salah satu konseli mengungkapkan bahwa.

"Hmm...tenggang rasa dan empati sepertinya sudah ada sih pak, tapi ada beberapa siswa juga belum muncul pak, ya.. saat sholat Dhuha, toh teman-teman juga banyak yang ramai saat baca surat Yasiin sebelum sholat Dhuha dimulai, kadang saya juga ngobrol dengan temen sebelah saya pak waktu sholat belum dimulai, kalo gak dilayani ngobrolnya ntar temenku marah, kan gak enak pak!! Terus ada lagi pak, biasanya saya suka clometan dengan guru saat pelajaran tertentu. Ya saya sadar itu salah, tapi temanteman saya memancing saya untuk nyeletuk berkata clometan pada guru yang sedang menerangkan pelajaran" (DW/KI/03/Mei/2014).

Fakta lapangan di atas dapat dimaknai bahwa konseli kurang memiliki sifat empati dalam hal penggunaan bahasa yang kurang etis. Penggunaan bahasa tidak baik merupakan salah satu tanda perilaku manusia yang menunjukkan arah kehancuran suatu bangsa (Lickona, 2012: 25-26). Hal ini berseberangan dengan apa yang diutarakan oleh Founding Fathers Indonesia "saya selalu diingatkannya agar dapat mikul dhuwur mendhem jero (memikul setinggi-tingginya, memendam sedalam-dalamnya; menghormat) terhadap orang tua" (DT2/1989/165/PA/Kal1).

Teks tersebut mengharapkan agar konseli mampu menjunjung tinggi, menghormati, menghargai dan menutup aib atau kesalahan orang tua ataupun guru. Kecapakan dalam mengahargai sangat diperlukan oleh konseli dalam rangka mewujudkan kehidupan saling menghormati antar sesama terutama terhadap guru. Kecakapan menghargai (respect) tersebut akan memunculkan orientasi karakter produktif dalam dinamika kehidupan sosial.

Orientasi karakter sosial meliputi dua hal yaitu berorientasi produktif dan nonproduktif meliputi reseptif (receptive), eksploitatif (exploitative), penimbun (hoarding), dan pemasaran (marketing) dan orientasi produktif merupakan karakter ideal (Feist \& Feist, 2008: 204-206; Friedman, 2013: 124; Fromm, 1975: 70-89; Schultz \& Schultz, 2005: 183-185).

Orientasi karakter produktif menjadi kebutuhan utama dalam menciptakan kehidupan yang baik. Orientasi karakter produktif terdiri dari kerja (working), cinta (loving), dan bernalar (reasoning) (Fromm, 1975: 117). Fakta lapangan yang telah dipaparkan pada paragraf sebelumnya mengindikasikan bahwa kemampuan bernalar menjadi kebutuhan utama dalam proses menciptakan pribadi menghargai. Kecakapan berpikir yang produktif meliputi empat komponen yaitu kepedulian (care), tanggungjawab (responsibility), penghargaan (respect) dan pengetahuan (knowledge) (Fromm, 1957: 104).

Berdasarkan penjelasan di atas, maka peneliti melakukan wawancara dengan salah satu konselor ikhwal karakter ideal yang diharapkan dalam diri konseli. Konselor dalam perbincangan mengutarakan.

"sebenernya sih.. kami ingin membuat anak didik kami punya pegangan agama yang kuat sebagai bekal mereka di masa depan kelak, ya..harapan kami bisa menjadi orang yang berakhlaq baik, artinya bahwa mereka dapat menaati aturan yang ada di Madrasah yang sudah bermuatan 
Islam dan pada akhirnya setelah lulus dari sini mereka dapat menjadi pribadi yang mampu memegang agama Islam dalam kehidupan masyarakat" (DW/KO/21/1/2014).

Pemaparan di atas menunjukkan bahwa konselor mengharapkan setiap konseli memiliki dimensi religiusitas yang kuat, konseli diharapkan memiliki pengetahuan agama, bertindak sesuai kaidah agama dan menerapkan dalam kehidupan sehari-hari. Hal ini sesuai dengan visi Madrasah berilmu, beramal, berakhlakul karimah dan berwawasan lingkungan sehingga diharapkan ketika konseli setelah menamatkan pembelajaran di madrasah mampu menerapkan ilmu agama yang telah diperoleh.

Berdasarkan harapan madrasah, ABKIN (2008: 253-258) juga telah berusaha menjabarkan karakteristik karakter ideal konseli yang terlihat dalam 11 aspek Standar Kemandirian Peserta Didik (SKKPD). Standar ini diharapkan dapat digunakan sebagai pedoman dalam melihat gambaran tahap perkembangan konseli yang harus dicapai, sehingga proses pemberian bantuan layanan bimbingan dan konseling dapat tercapai secara maksimal. Terkait hal tersebut, pemerintah juga memiliki visi yang sama dalam konteks lebih makro (luas) yakni berusaha membangun manusia Indonesia yang memiliki karakter pribadi ideal. Hal ini terlihat dalam UUD pasal 20 tahun 2003 Tentang Sistem Pendidikan Nasional dalam pasal I seperti tampak sebagai berikut.

Pendidikan adalah usaha sadar dan terencana untuk mewujudkan suasana belajar dan proses pembelajaran agar peserta didik secara aktif mengembangkan potensi dirinya untuk memiliki kekuatan spiritual keagamaan, pengendalian diri, kepribadian, kecerdasan, akhlak mulia, serta keterampilan yang diperlukan dirinya, masyarakat, bangsa dan Negara.

Dasar hukum di atas terlihat jelas bahwa pemerintah berusaha menguraikan dimensi karakter ideal manusia Indonesia. Dimensi tersebut terdapat dalam "pengembangan potensi diri" yang ingin dibentuk mencakup ranah afektif, kognitif dan psikomotor. Hal ini diharapkan dapat membantu mewujudkan karakter ideal bagi manusia Indonesia. Gambaran karakter tersebut diharapkan dapat diterapkan dalam seting bimbingan dan konseling yaitu terkait konsep karakter ideal konseli. Konsep karakter tersebut dapat digunakan konselor sebagai acuan dalam memberikan layanan bimbingan pada konseli secara maksimal.

Berdasarkan fenomena lapangan dan setelah dilakukan penelusuran makna dengan teknik hermeneutik ditemukan beberapa bongkahan makna yang perlu dipertanyakan. Pertama wacana hidup produktif berasal dari fakta lapangan bergaya hidup mewah yang berbenturan dengan teks kepribadian
Founding Fathers Indonesia hidup efektif. Kedua, makna kerjasama diperoleh dari teks kepribadian Founding Fathers Indonesia tentang perilaku gotongroyong. Ketiga, wacana perilaku menghargai berasal perilaku empati siswa terhadap guru yang bertolak belakang dengan teks kepribadian Founding Fathers Indonesia.

Ketiga makna yang telah dipaparkan di atas dapat disimpulkan bahwa kajian tema penelitian mencakup hidup produktif, kerjasama, perilaku menghargai dan nilai karakter lain mengindikasikan bahwa dirasa perlu dilakukan penelusuran karakter ideal konseli dalam serpihan teks kepribadian Founding Fathers Indonesia. Penelusuran makna teks dapat dilakukan dengan metode hermeneutik sebagai ancangan analisis. Mappiare (2013: 115) menyebutkan bahwa hermeneutik merupakan tipe riset kualitatif yang memfokus pada kesadaran dan pengalaman manusia dalam teks.

Hermeneutik secara sederhana merupakan ilmu yang menafsirkan teks (Raharjo, 2008: 27, Endraswara, 2006: 42). Hermeneutik yang digunakan dalam penelitian ini menggunakan hermeneutik Gadamerian, yaitu hermeneutik dialektis dimana ada pola naik turun antara Part (bagian) dan Whole (keseluruhan) untuk mengetahui makna sentral yang ingin digali dalam sebuah teks (Alvesson \& Skoldberg, 2000: 53). Proses pencarian makna sentral akan terjadi fusion the horizon (gabungan cakrawala) antara bias-bias budaya sang penafsir (peneliti) dengan budaya yang dibawa teks sehingga produk akhir adalah muncul sebuah keseragaman atau kesepakatan makna antara sang penafsir (interpreter) dan teks (interpreted). Dalam konteks ini peneliti berusaha memahami kesadaran makna karakter ideal konseli yang diharapkan oleh teks kepribadian Founding Fathers Indonesia.

\section{METODE}

Metode penelitian dalam riset ini menggunakan pendekatan kualitatif. Bogdan dan Taylor (1975: 4) mendefinisikan bahwa metode kualitatif sebagai "qualitative methodologies refer to research procedures which procedure descriptive data: people's own written or spoken words and observable behavior". Pendapat di atas menunjukkan bahwa cakupan penelitian kualitatif yaitu menghasilkan data deskriptif berupa kata-kata tertulis atau lisan dari orang-orang dan perilaku yang diamati. Berdasarkan pendapat tersebut dalam upaya mendeskripsikan kata-kata tertulis di dalam teks maka penelitian ini menggunakan rancangan kualitatif dengan tipe hermeneutik Gadamerian. Alasan penggunaan tipe hermeneutik karena untuk menafsirkan simbol, tindakan teks dan bentuk material lainnya. Pokok pemikiran hermeneutik Gadamerian yaitu terdapat sebuah pola lingkaran hermeneutik (hermeneutic circle). Lingkaran tersebut terdiri dari pola naik turun antara bagian (part) dan keseluruhan (whole) untuk memahami makna dalam sebuah teks. Hal ini berarti bagian (part) akan mengubah pemahaman kita pada keseluruhan dan sebaliknya pengubahan pada pemahaman kita terhadap keseluruhan (whole) 
akan mengubah pemahaman kita pada bagian dan seterusnya (Rahardjo, 2008: 118).

Sumber data penelitian ini menggunakan data dokumentasi berupa buku teks. Sumber data teks dibagi menjadi dua sumber data yaitu data primer dan data sekunder. Buku sumber teks yang digunakan dalam penelitian ini terdiri dari 5 buku yaitu : 1) Sukarno-Penyambung Lidah Rakyat Indonesia karangan Cindy Adams; 2) Soeharto: Pikiran, Tindakan dan Ucapan Saya karangan K.H Ramadhan dan Dwipayana; 3) Anak Desa: Biografi Presiden Soeharto, karangan O.G. Roeder; 4) Dibawah Bendera Revolusi Jilid I, karangan Ir. Soekarno; dan 5) Dibawah Bendera Revolusi Jilid II, karangan Ir. Soekarno. Sebagai tambahan sumber, peneliti juga menggunakan data sekunder yaitu data wawancara, observasi lapangan di situs sejarah, buku-buku teori, jurnal dan laporan tesis yang serupa dengan kajian sebagai penguat penelitian.

Prosedur pengumpulan data yang dilakukan dalam penelitian meliputi: 1) mencari sumber primer yaitu buku teks kepribadian Founding Fathers Indonesia; 2) mengumpulkan data sekunder, yaitu buku yang berkaitan dengan wacana Founding Fathres Indonesia dan 3) Proses Reduksi data yaitu dilakukan dengan menetapkan dan mengumpulkan sumbersumber yang sesuai dengan tujuan penelitian serta membuang data yang tidak diperlukan.

Instrumen penelitian adalah peneliti, hal ini sesuai pendapat Patterson \& Williams (2002: 42) from an hermeneutic perspective, the researcher must adopt the role of "self as instrument". Digunakan peneliti sebagai instrumen di dasari oleh alasan bahwa upaya menggali dan memaknai nilai karakter ideal konseli dalam teks kepribadian Founding Fathers Indonesia diperlukan peran peneliti (penafsir) secara intensif dan mendalam. Oleh sebab itu dalam proses kegiatan penelitian, peneliti dibantu oleh rambu-rambu tentang pengklasifikasian karakter ideal konseli yang meliputi: 1) Peneliti membaca dan menandai sumber data lebih dari dua kali; 2) Peneliti membaca kembali sesuai dengan keperluan untuk menandai mencatat, dan mengutip dengan sticky notes bagian-bagian yang dijadikan data penelitian; 3) Peneliti mengidentifikasi dan mengklasifikasi data sesuai dengan masalah penelitian, yaitu hidup produktif, perilaku kerjasama, menghargai dan nilai karakter lain.

Analisis data yang digunakan dalam penelitian ini menggunakan teknik part-whole. Data yang dianalisis berupa hasil pemaknaan dan interpretasi dari pengkajian buku teks Founding Fathers Indonesia. Dalam perspektif hermeneutik Gadamerian, analisis data disebut lingkaran hermeneutik (hermeneutic circle) (Alvesson dan Skoldberg, 2000: 53). Mappiare (2013: 123) yang menjelaskan langkah-langkah dalam melakukan analisis hermeneutik Gadamerian meliputi (1) penafsiran bagian-bagian, unsur atau bagian (part), (2) penafsiran keseluruhan, keutuhan (whole) dan (3) mendapatkan pemahaman pada yang melandasi makna (understanding of underlying meaning).

Pengecekan keabsahan data dilakukan dengan triangulasi data untuk menjaga keabsahan data. Triangulasi merupakan teknik pemeriksaan data yang memanfaatkan sesuatu yang lain di luar data untuk keperluan pengecekan atau sebagai pembanding terhadap itu agar terhindar dari bias subjektif peneliti (Miles \& Hubberman, 1984: 234-235). Triangulasi data dalam penelitian ini dilakukan dengan mendiskusikan data dengan ahli (dosen pembimbing yang memiliki pengetahuan tentang Founding Fathers).

Tahap-tahap penelitian yang dilakukan dalam penelitian ini diawali dengan berusaha menemukan fokus persoalan (permasalahan) yang akan menjadi tema kajian penelitian. Setelah persoalan penelitian ditemukan maka langkah berikutnya menyusun desain atau rancangan penelitian yang akan menjadi pedoman bagi peneliti dalam melaksanakan kegiatan. Pendekatan yang digunakan peneliti adalah pendekatan kualitatif dengan tipe hermeneutik Gadamerian. Pertama, menetapkan buku teks yang akan dijadikan bahan analisis hermeneutik. Proses penetapan buku melalui tahapan: 1) Praandaian adalah upaya untuk menfasirkan atau menggambarkan makna apa yang ingin diperoleh dalam penelitian terhadap teks yang sedang dikaji. Adapun langkah-langkah yang ditempuh oleh peneliti pada tahap praandaian antara lain: a) membaca berulang-ulang, b) menentukan fokus penelitian yang dapat diserap sebagai karakter ideal konseli, dan c) membaca buku sumber yang relevan dengan fokus penelitian; 2) Realitas historis yang terdiri dari beberapa langkah: a) Pembentukan data, dilakukan dengan membaca dan mengkaji buku-buku yang sesuai dengan kajian yang dilakukan. Dalam prosedur ini, dari setiap buku yang relevan dikutip atau dijelaskan sesuai dengan tulisan asli maupun dengan memberikan kesimpulan sendiri; b) Pereduksian data, bertujuan untuk mengurangi data yang tidak memiliki relevansi dengan tujuan penelitian sehingga data dipadukan untuk proses analisis yaitu gambaran karakter ideal konseli; c) Penarikan inferensi merupakan tafsiran makna kata-kata atau pesan maupun simbol-simbol yang dituturkan oleh Founding Fathers Indonesia dalam buku sumber. Tafsiran tersebut didasarkan pada konteks budaya dan historis; d) Analisis data dilakukan dengan teknik part-whole; 3) Hasil kajian (produksi) Memperoleh gambaran atau deskripsi tentang gambaran karakter ideal konseli yang diwacanakan oleh Founding Fathers Indonesia.

\section{HASIL DAN PEMBAHASAN}

Hasil pengkajian teks kepribadian FFI menghasilkan empat bahasan yaitu deskripsi hidup produktif, deskripsi perilaku kerjasama, deskripsi menghargai dan nilai karakter lain yang meliputi nasionalis dan religius.

Deskripsi hidup sederhana meliputi aspek pola hidup sederhana, dinamis dan kerja keras, tidak bergantung pada bangsa lain, positivisme dan dinamika, cinta produk dalam negeri, pantang menyerah, normatif, semangat bekerja, keseimbangan kebutuhan jasmani dan rohani, inovatif, rela berkoran, kontrol diri, manajemen waktu, kerja keras dan penguasaan iptek, rasional dan demokratis, dan kebebasan-terarah. Aspek yang telah disebutkan kemudian dikaji secara teoretis menghasilkan beberapa aspek yaitu: pola hidup sederhana, kontrol diri, 
dinamis, tidak bergantung pada bangsa lain, cinta produk dalam negeri, normatif, inovatif, rela berkorban dan kebebasan-terarah.

Deskripsi perilaku kerjasama meliputi aspek saling membantu, rasa setiakawan, persatuan, kebersamaan, kekeluargaan, semangat kerjasama, asas normatif, kesesuaian pedoman, dan menghargai kedaulatan bangsa. Aspek yang telah disebutkan kemudian dikaji secara teoretis menghasilkan beberapa aspek yaitu rasa setiakawan, kesesuaian pedoman, dan menghargai kedaulatan bangsa.

Deskripsi menghargai meliputi aspek musyawarah dan mufakat, lapang dada, bijaksana, sopan santun, dan sabar, menghargai orang tua, menghargai nama bangsa, menghargai budaya, menghargai sejarah, menghargai sesama, menghargai alam semesta dan toleransi. Aspek yang telah disebutkan kemudian dikaji secara teoretis menghasilkan beberapa aspek yaitu musyawarah dan mufakat, bijaksana dan toleransi

Nilai karakter lain yang meliputi religuis dan nasionalis. Deskripsi religius meliputi aspek keyakinan, toleransi antar agama, pancasila sebagai pedoman, rasionalitas, keimanan, dan pengabdian. Aspek yang telah disebutkan kemudian dikaji secara teoretis menghasilkan beberapa aspek yaitu keimanan, pancasila sebagai pedoman dan rasional. Deskripsi nasionalis meliputi aspek humanisme, rasa kebangsaan, pengabdian, persatuan, cinta-damai, dan pembangunan ideologi. Aspek yang telah disebutkan kemudian dikaji secara teoretis menghasilkan beberapa aspek yaitu humanis, persatuan dan cinta-damai. Sajian keeempat karakter dapat tersaji pada tabel sebagi berikut.

\begin{tabular}{|c|c|c|}
\hline No & $\begin{array}{l}\text { Dimensi } \\
\text { Karakter }\end{array}$ & Aspek \\
\hline \multirow[t]{11}{*}{$\mathrm{A}$} & \multirow{11}{*}{$\begin{array}{l}\text { Hidup } \\
\text { Produktif }\end{array}$} & 1. Pola Hidup Sederhana \\
\hline & & 2. Kontrol Diri \\
\hline & & 3. Dinamis \\
\hline & & 4. Tidak Bergantung Pada \\
\hline & & Bangsa Lain \\
\hline & & 5. Cinta Produk dalam \\
\hline & & Negeri \\
\hline & & 6. Normatif \\
\hline & & 7. Inovatif \\
\hline & & 8. Rela Berkorban \\
\hline & & 9. Kebebasan-Terarah \\
\hline \multirow[t]{3}{*}{$\mathrm{B}$} & \multirow{3}{*}{$\begin{array}{l}\text { Perilaku } \\
\text { Kerjasama }\end{array}$} & 1. Rasa setiakawan \\
\hline & & 2. Kesesuaian pedoman \\
\hline & & $\begin{array}{l}\text { 3. Menghargai kedaulatan } \\
\text { bangsa }\end{array}$ \\
\hline \multirow[t]{4}{*}{$\mathrm{C}$} & \multirow[t]{4}{*}{ Menghargai } & 1. Musyawarah dan \\
\hline & & Mufakat \\
\hline & & 2. Bijaksana \\
\hline & & 3. Toleransi \\
\hline \multirow[t]{4}{*}{$\mathrm{D}$} & \multirow[t]{4}{*}{ Religuis } & 1. Keyakinan \\
\hline & & 2. Pancasila sebagai \\
\hline & & Pedoman \\
\hline & & 3. Rasional \\
\hline \multirow[t]{2}{*}{$\mathrm{E}$} & \multirow[t]{2}{*}{ Nasionalis } & 1. Humanis \\
\hline & & 2. Persatuan \\
\hline
\end{tabular}

\section{Cinta-Damai}

Pembahasan keempat karakter yang telah didapat dikombinasikan dengan aspek perkembangan peserta didik dalam Standar Kemandirian Peserta Didik (SKKPD). Penjelasan tersebut dapat dilahat pada tabel sebagi berikut.

\begin{tabular}{|c|c|c|c|c|}
\hline $\begin{array}{l}\mathrm{N} \\
\mathrm{O}\end{array}$ & $\begin{array}{l}\text { Dimens } \\
\text { i } \\
\text { Karakt } \\
\text { er }\end{array}$ & Aspek & $\begin{array}{l}\text { Aspek } \\
\text { Perkemb } \\
\text { angan }\end{array}$ & SKKPD \\
\hline $\mathrm{A}$ & $\begin{array}{l}\text { Hidup } \\
\text { Produk } \\
\text { tif }\end{array}$ & $\begin{array}{ll}\text { 1. } & \text { Pola } \\
\text { Hidup } \\
\text { Sederha } \\
\text { na }\end{array}$ & $\begin{array}{l}\text { Perilaku } \\
\text { kewiraus } \\
\text { ahaan } \\
\text { (kemandi } \\
\text { rian } \\
\text { Perilaku } \\
\text { Ekonomi }\end{array}$ & $\begin{array}{l}\text { Menampil } \\
\text { kan hidup } \\
\text { hemat, } \\
\text { ulet, } \\
\text { sungguh- } \\
\text { sungguh, } \\
\text { dan }\end{array}$ \\
\hline
\end{tabular}

Ekonomi dan

s) kompetitif

atas dasar

kesadaran

sendiri

2. Kontrol Perilaku Mempelaja Diri kewiraus ri strategi ahaan dan (kemandi peluang rian untuk Perilaku berperilak

Ekonomi u, hemat, s) ulet, sungguhsungguh, dan kompetitif dalam keragaman kehidupan

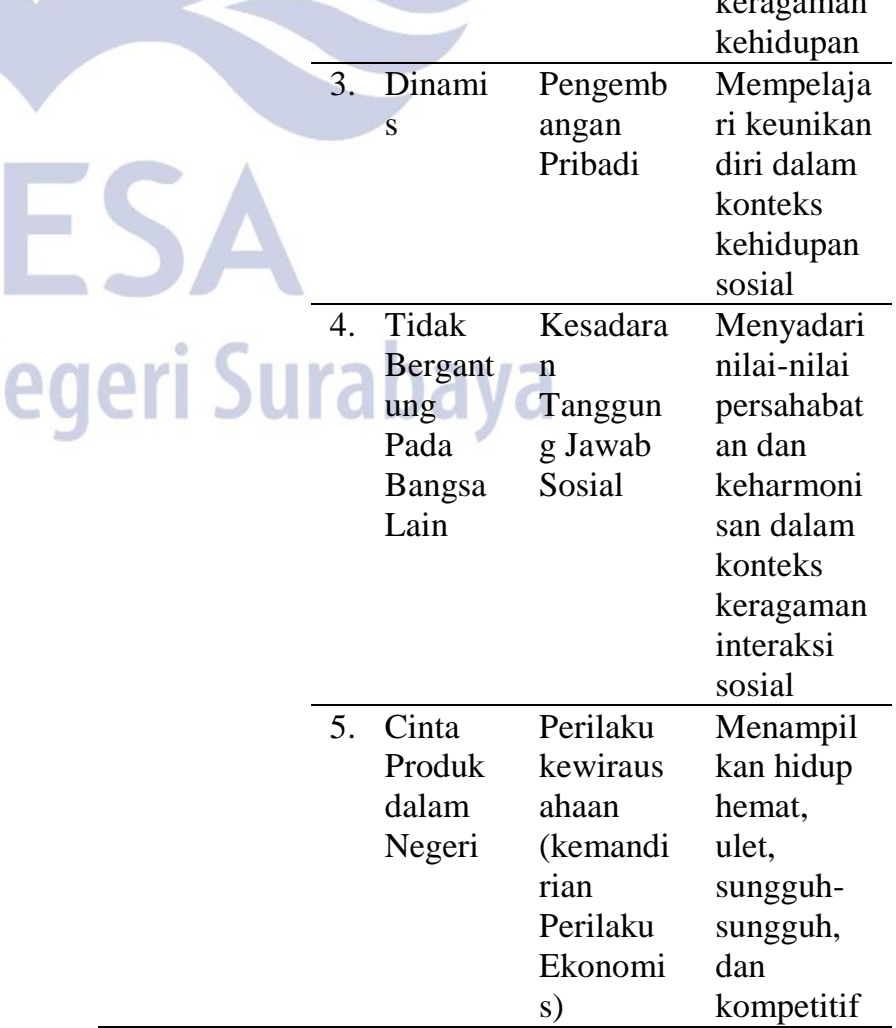


atas dasar

kesadaran

sendiri

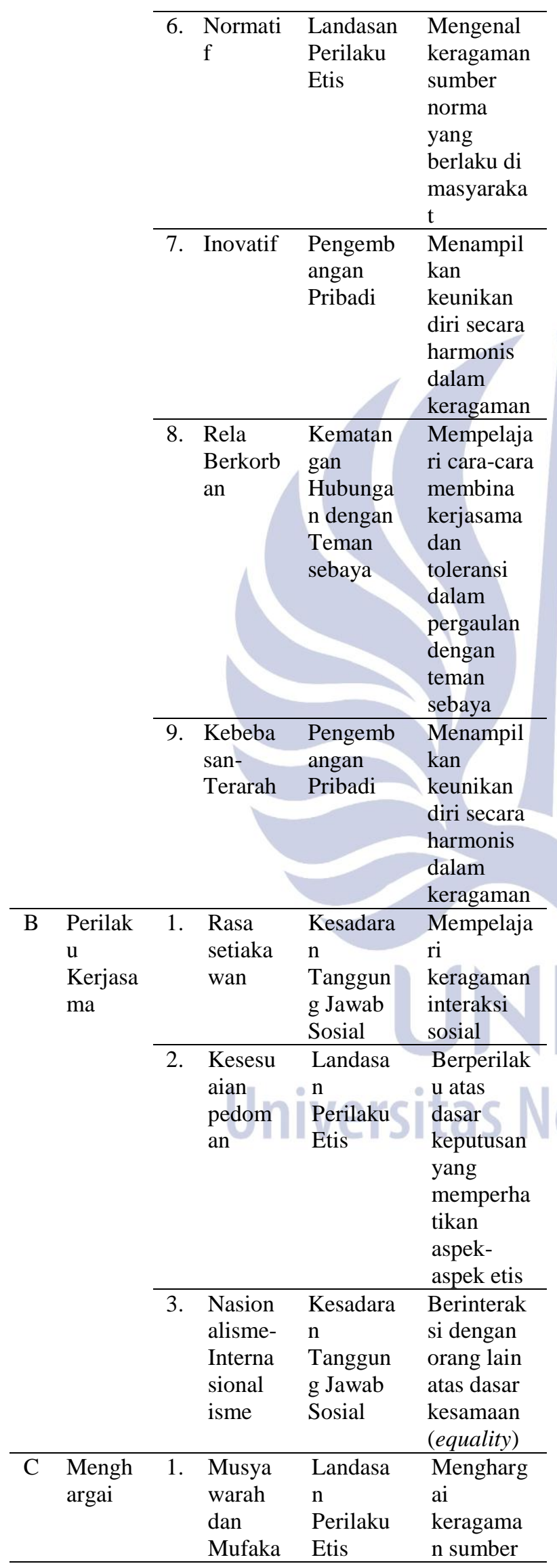

\begin{tabular}{|c|c|c|c|}
\hline & $\mathrm{t}$ & & $\begin{array}{l}\text { norma } \\
\text { sebagai } \\
\text { rujukan } \\
\text { pengambil } \\
\text { an } \\
\text { keputusan }\end{array}$ \\
\hline & $\begin{array}{l}\text { 2. Bijaksa } \\
\text { na }\end{array}$ & $\begin{array}{l}\text { Landasa } \\
\mathrm{n} \\
\text { Perilaku } \\
\text { Etis }\end{array}$ & $\begin{array}{l}\text { Berperilak } \\
\text { u atas } \\
\text { dasar } \\
\text { keputusan } \\
\text { yang } \\
\text { memperha } \\
\text { tikan } \\
\text { aspek- } \\
\text { aspek etis }\end{array}$ \\
\hline & $\begin{array}{ll}3 . & \text { Toleran } \\
& \text { si }\end{array}$ & $\begin{array}{l}\text { Kematan } \\
\text { gan } \\
\text { Emosi }\end{array}$ & $\begin{array}{l}\text { Bersikap } \\
\text { toleran } \\
\text { terhadap } \\
\text { ragam } \\
\text { ekspesi } \\
\text { perasaan } \\
\text { diri sendiri } \\
\text { dan orang } \\
\text { lain } \\
\end{array}$ \\
\hline D Religui & $\begin{array}{l}\text { 1. Keyaki } \\
\text { nan }\end{array}$ & $\begin{array}{l}\text { Landasan } \\
\text { Religius }\end{array}$ & $\begin{array}{l}\text { Mempelaja } \\
\text { ri hal } \\
\text { ikhwal } \\
\text { ibadah }\end{array}$ \\
\hline & $\begin{array}{l}\text { 2. Pancasi } \\
\text { la } \\
\text { sebagai } \\
\text { Pedom } \\
\text { an }\end{array}$ & $\begin{array}{l}\text { Landasan } \\
\text { Religius }\end{array}$ & $\begin{array}{l}\text { Mengemba } \\
\text { ngkan } \\
\text { pemikiran } \\
\text { tentang } \\
\text { kehidupan } \\
\text { beragama }\end{array}$ \\
\hline & $\begin{array}{l}\text { 3. } \begin{array}{l}\text { Rasion } \\
\text { al }\end{array} \\
\text { a }\end{array}$ & $\begin{array}{l}\text { Landasan } \\
\text { Religius }\end{array}$ & $\begin{array}{l}\text { Mengemba } \\
\text { ngkan } \\
\text { pemikiran } \\
\text { tentang } \\
\text { kehidupan } \\
\text { beragama } \\
\end{array}$ \\
\hline $\begin{array}{l}\text { E Nasion } \\
\text { alis }\end{array}$ & $\begin{array}{l}\text { 1. Human } \\
\text { is }\end{array}$ & $\begin{array}{l}\text { Kesadara } \\
\mathrm{n} \\
\text { Tanggun } \\
\text { g Jawab } \\
\text { Sosial }\end{array}$ & $\begin{array}{l}\text { Mempelaja } \\
\text { ri } \\
\text { keragaman } \\
\text { interaksi } \\
\text { sosial }\end{array}$ \\
\hline Q & $\begin{array}{l}\text { 2. Persatu } \\
\text { an }\end{array}$ & $\begin{array}{l}\text { Kesadara } \\
\mathrm{n} \\
\text { Tanggun } \\
\text { g Jawab } \\
\text { Sosial }\end{array}$ & $\begin{array}{l}\text { Berinterak } \\
\text { si dengan } \\
\text { orang lain } \\
\text { atas dasar } \\
\text { kesamaan } \\
\text { (equality) }\end{array}$ \\
\hline & $\begin{array}{l}\text { 3. Cinta- } \\
\text { Damai }\end{array}$ & $\begin{array}{l}\text { Kesadara } \\
\mathrm{n} \\
\text { Tanggun } \\
\text { g Jawab } \\
\text { Sosial }\end{array}$ & $\begin{array}{l}\text { Menyadari } \\
\text { nilai-nilai } \\
\text { persahabat } \\
\text { an dan } \\
\text { keharmoni } \\
\text { san dalam } \\
\text { konteks } \\
\text { keragaman } \\
\text { interaksi } \\
\text { sosial }\end{array}$ \\
\hline
\end{tabular}


Penjabaran aspek dalam SKKPD dan karakter beserta aspek yang telah dipaparkan pada tabel di atas dapat disimpulkan bahwa apa yang diwacanakan oleh FFI dalam teks dapat diserap dalam bimbingan dan konseling. Hal ini berarti bahwa dimensi manusia yang dipaparkan oleh FFI senada dengan konsep dimensi konseli dalam SKKPD. Berdasarkan temuan dan kajian yang telah dilakukan, maka kajian berharga ini dapat digunakan oleh konselor sebagai bahan rujukan dalam upaya pemahan konseli. Upaya pemahan tersebut didasari oleh kemajuan era globalisasi saat ini yang menutut konselor lebih memahami makna kebebasan individu secara mendasar dengan berpijak pada landasan filosofis manusia Indonesia seutuhnya.

\section{PENUTUP \\ Simpulan}

Berdasarkan hasil dan pembahasan penelitian maka dapat disimpulkan bahwa identifikasi karakter ideal konseli menurut teks kepribadian Founding Fathers Indonesia (FFI) meliputi pola hidup produktif, perilaku kerjasama, menghargai, nilai kepribadian lain yang meliputi dua yaitu religius dan nasionalis. Karakter yang ditemukan tersebut terdiri dari beberapa aspek yang meliputi: Pertama, Pola hidup produktif terdiri dari; Pola Hidup Sederhana, Kontrol Diri, Dinamis, Tidak Bergantung Pada Bangsa Lain, Cinta Produk dalam Negeri, Pantang Menyerah, Normatif, Inovatif, Rela Berkorban, dan Kebebasan-Terarah. Kedua, Perilaku Kerjasama meliputi; Rasa setiakawan, Persatuan, Kesesuaian pedoman, dan Menghargai kedaulatan bangsa. Ketiga, Menghargai yang meliputi; Musyawarah dan Mufakat, Bijaksana, dan Toleransi. Keempat, Religius meliputi: Keyakinan, Pancasila sebagai Pedoman, Rasional, dan Keimanan. Kelima, Nasionalis meliputi: Humanis, Persatuan, dan CintaDamai. Temuan penelitian meliputi kelima kajian karakter bersinergi dengan beberapa aspek perkembangan dalam SKKPD. Hal ini dapat disimpulkan bahwa Identifikasi Karakter Ideal Konseli dalam teks karakter FFI dapat diserap dalam bimbingan dan konseling terutama pemahaman tentang konseli secara utuh.

\section{Saran}

Berdasarkan simpulan hasil kajian teks yang telah dijelaskan di atas, maka dikemukakan saran untuk guru $\mathrm{BK} /$ Konselor sebagai pengguna dan saran untuk

\section{DAFTAR PUSTAKA}

\section{ABKIN. 2008. Penataan Pendidikan Profesional} Konselor dan Layanan Bimbingan dan Konseling dalam Jalur Pendidikan Formal. Jakarta: Depdiknas.

Adams, C. 2001. Bung Karno Penyambung Lidah Rakyat Indonesia. Jakarta: PT. Tema Baru.

Alvesson, M \& Skoldberg, K. 2000. Reflexive Methodology New Vistas For Qualitative Research. London: SAGE Publication. penelitian lanjutan. Kedua hal tersebut dijelaskan sebagai berikut.

1. Saran untuk Guru BK/ Konselor

a. Identifikasi karakter ideal konseli dari teks kepribadian menurut FFI dapat diterapkan oleh

konselor sekolah untuk meningkatkan pemahaman terhadap konseli yang akan diberikan layanan.

b. Konselor dapat memanfaatkan hasil penelitian dengan memahami dan memaknai karakter konseli sebagai dasar melakukan layanan konseling.

2. Saran untuk Penelitian Lanjut

a. Penelitian ini dilakukan dalam konteks siswa Madrasah, untuk peneliti selanjutnya dapat dilakukan pada Sekolah Menengah Atas (SMA) agar diperoleh gambaran lain tentang kondisi karakter konseli dalam seting pendidikan yang berbeda.

b. Penelitian ini menggunakan pendekatan hermeneutik Gadamerian, untuk peneliti selanjutnya dapat menggunakan desain penelitian lain seperti Hermeneutik Fenomenologis, Hermeneutik Paul Ricoeur, Reflexive Methodology Skoldberg dan Alvesson maupun viarian hermeneutik yang lain agar kajian teks menjadi lebih kaya dalam upaya penggalian makna.

c. Penelitian ini menggunakan Erich Fromm sebagai teori utama dalam menyingkapi makna karakter yang terdapat dalam teks, untuk peneliti selanjutnya dapat menggunakan teori lain dalam rumpun humanis seperti Carls Rogers, Abaraham H. Maslow, dan Rollo May maupun rumpun teori konseling yang lain baik dari barat maupun Indonesia agar pemahaman makna kebebasan konseli dalam era kehidupan modern dapat tergambar dengan baik dan cermat.

d. Penelitian ini menggunakan buku Sukarno dan Suharto sebagai acuan, untuk peneliti selanjutnya dapat menggunakan buku-buku mengenai tokoh-tokoh sejarah yang menginspirasi perjuangan bangsa Indonesia seperti H.O.S. Cokroaminoto, Tan Malaka, Pramoedya Ananta Toer, maupun tek-teks budaya bangsa Indonesia seperti serat budaya.

Bogdan, R \& Taylor, S.J,. 1975. Introduction To Qualitative Research Methods.Canada: Wiley Interscience Publication.

Dwipayana, G \& KH. Ramadhan. 1989. Soeharto Pikiran, Ucapan, dan Tindakan Saya. Jakarta: PT. Citra Lamtoro Gunung Persada.

Endraswara, Suwardi. 2008. Metodologi Penelitian Sastra Epistemologi, Model, Teori, dan Aplikasi (Edisi Revisi).Yogyakrta: MedPress.

Feist, J \& Feist, G.J, 2008. Theories of Personality Seven Edition. USA: McGraw-Hill Companies. 
Feist, J. \& Feist, G.J. 2008. Teori Kepribadian.

Terjemahan Smita Prathita Sjahputri. 2011.

Jakarta: Salemba Humanika.

Friedman, L.J. 2013. The Lives of Erich Fromm Love's Prophet. USA: Columbia University Press.

Fromm, E. 1955. The Sane Society. New York: Holt, Rinehart and Winston.

Fromm, E. 1975. Man for himself: An inquiry into the psychology of ethics. New York: Holt, Rinehart and Winston.

Fromm, E. 1957. The Art of Loving. Great Britain: George Allen \& Unwin Publishers.

Fromm, E. 1976. To Have or to Be. USA: Continuum.

Fromm, E. 1976. Selfishness and Self-Love. Journal for the Study of Interpersonal Process Vol 2 507-523 1939b, (online)

(http://www.ualberta.ca/ iiqm/backissues/2_3f inal/pdf/laverty.pdf), diakses 7 Agustus 2014.

Funk, R. 2009. The Clinical Erich Fromm Personal Accounts and Papers on Therapeutic Technique. New York: Amsterdam.

Lickona, T. 1991. Educating for Character.

Terjemahan Juma Abdu Wamaungo. 2012. Jakarta: Bumi Aksara.

Mappiare, AT. 2013. Tipe-Tipe Metode Riset Kualitatif untuk Eksplanasi Sosial Budaya dan Bimbingan Konseling. Malang: Elang Mas.

Miles, M.B. \& Hubberman, A.M. 1984. Qualitative Data Analysis. USA: SAGE Publications.

Patterson, M.E. \& Williams, D.R. 2002. Collecting and Analyzing Qualitatif Data: Hermeneutic Principle, Methods, and Case Sample. USA: Sagamore Publishing.

Rahardjo, M. 2008. Hermeneutika Gadamerian Kuasa Bahasa dalam Wacana Politik Gus Dur. Malang: UIN-Malang Press.

Roeder, O.G. 1977. Anak Desa: Biografi Presiden Soeharto. Jakarta: Gunung Agung

Scultz, D.P, \& Schultz, S.E. 2005. Theories of Personality Eight Edition. USA: Wardsworth.

Sukarno. 1965. Dibawah Bendera Revolusi Jilid I Cetakan Kedua. Jakarta: Panitia Penerbit Dibawah Bendera Revolusi.

Sukarno. 1965. Dibawah Bendera Revolusi Jilid II Cetakan Kedua. Jakarta: Panitia Penerbit Dibawah Bendera Revolusi.

Undang-Undang RI No.20 Tahun 2003 tentang Sistem Pendidikan Nasional.Jakarta. 